\title{
Determining fetal sex in pregnancy with reference to pregnant women behavior in late pregnancy
}

\begin{abstract}
Introduction. Pregnant women often create their own image of a child. The ultrasound is able to model and modify this picture. The image of the unborn child develops along with the process of creating the space for the baby on the psychological and emotional level and is continued after the delivery.

Aim. The authors of the study made an attempt to evaluate the influence of fetal sex determination during ultrasound in pregnancy on emotional and 'practical' experiencing late pregnancy - after the $28^{\text {th }}$ week of its duration.

Material and methods. The study included 200 pregnant women. Qualification criteria for the research was the declared awareness of fetal sex confirmed by ultrasound. Among others, factors influencing decision to determine fetal sex, emotional bond with the unborn child after identifying the sex, as well as preparation for birth regarding prognosticated sex were assessed.

Results. Nearly all pregnant women wanted to find out the fetal sex, usually claiming that they did so out of curiosity. After they did it, about $2 / 3$ of them stated that the emotional bond with the baby increased and the vast majority of women started preparing layettes for their future babies.

Conclusions. Determination of fetal sex during ultrasound improves the relationship between the mother and her future baby. It also enables the woman to prepare for childbirth considering its sex by the purchase of clothes, pram and preparation of layette or baby's room.
\end{abstract}

Keywords: fetal sex, pregnancy, third trimester, ultrasound.

DOI: $10.1515 /$ pjph-2015-0030

\section{INTRODUCTION}

Pregnant women often create their own image (i.e. imaginary representation) of a baby. Creating an emotional bond between the mother and the child is a process that evolves during pregnancy and is continued after the delivery. Women who treat their babies as individuals attribute certain characteristics and qualities to them. This means, they create a socalled picture of an 'imagined baby' [1]. Ultrasound is able to model and modify this picture. The image of the unborn child develops along with the process of creating the space for the baby on the psychological and emotional level. This opens the door for adequate assessment of the child's needs when it is born [2]. Benoit et al., while evaluating maternal representations of a baby in the third trimester of pregnancy, attempted to predict the quality of mother's attachment to her baby in its twelfth month of life. Study results revealed that psychological life of the pregnant woman essentially affects baby's attachment to its mother. Maternal representations of her baby in pregnancy significantly shape biological, sociological and psychological health of a baby [3].
According to Siddiqui et al., an emotional bond between the pregnant woman and the unborn child is a multidimensional construction which is due to the variety of determining factors [4]. Recognizing the factors affecting the formation of emotional bond in the prenatal period is significant because of the future emotional and psychological functioning of the baby as well as building good relationships in the family system. A prenatal determination of the child's sex is one of the factors determining the emotional bond between a mother and her unborn child.

\section{AIM}

The aim of the study was to assess the extent to which a determination of the fetal sex (identified during USG examination in pregnancy) influences the emotional and 'practical' experience of late pregnancy (of the third trimester). Therefore, the reasons of desire to know fetal sex, the influence of fetal sex determination on creating attachment with the unborn child, emotions accompanying pregnancy as well as concerns connected with acquiring information

\footnotetext{
${ }^{1}$ The Department of Obstetrics, Gynecology and Gynecological and Obstetric Nursing, Faculty of Health Sciences of the Medical University in Lublin, Poland

${ }^{2}$ Diagnostic Techniques Unit, Faculty of Health Sciences of the Medical University in Lublin, Poland

${ }^{3}$ Midwifery student, Faculty of Health Sciences, Medical University in Lublin, Poland
} 
about baby's sex through ultrasound were analyzed. Moreover, the extent of 'practical' preparations considering forecasting child's sex was assessed.

\section{MATERIAL AND METHODS}

The study looked at 200 pregnant women. The declared awareness of fetal sex obtained through ultrasound was a qualification criterion for the research study. Respondents were in the third trimester of pregnancy - between $29^{\text {th }}$ and $41^{\text {st }}$ week of its duration. The surveyed found out the sex of their fetus between the $19^{\text {th }}$ and $36^{\text {th }}$ week of pregnancy in the $22^{\text {nd }}$ week on average.

Survey questionnaire was used during the purpose of the study. Participation in the survey was entirely voluntary and anonymous.

The relationship between the features was verified through the use of Pearson's Chi-Square uniformity tests. The level of essentiality $p=0.005$ was assumed to state statistically significant differences or relations.

Statistical studies were conducted basing on statistical software package Statistica 9.0 (StatSoft Poland).

\section{RESULTS}

The majority (91.5\%) of the investigated pregnant women wanted to know fetal sex during ultrasound. They claimed they had done it out of curiosity (77.6\%). More than half of the pregnant $(51.5 \%)$ had no specific expectations concerning the baby's sex. An analysis of the collected data revealed that the emotional bond increases most among the subjects with unplanned pregnancies - it concerns $79.63 \%$ of the surveyed, while it concerns $58.22 \%$ of women previously planning their pregnancies. This difference is statistically significant: $\mathrm{p}<0.005$. For the considerable majority - some $88.5 \%$ of the surveyed women - determining the sex of an unborn aroused positive emotions and experiencing happiness. 39\% of the surveyed had doubts about the sex determined during USG examination and they requested additional USG examination in order to confirm the identified sex. Only $12 \%$ of the surveyed indicated determination of the baby's sex as a need to prepare its layette, however, as much as $76 \%$ of the pregnant declared that USG examination and identifying baby's sex let them start the 'practical' preparation for a childbirth, by purchasing the right clothes, pram, preparing the layette or baby's room.

\section{DISCUSSION}

People in the past wanted to find out their children sex since ancient times. Back then, future parents tried to predict the child's sex, in order to fulfill their own expectations about their offspring. Such practices were risky, as in case of failure, the clairvoyant could pay with their life [5]. At present, we have a range of diagnostic tools that allow one hundred percent determination of the sex of the unborn child. Using prenatal assessment of the amniotic cell culture karyotype obtained from amniocentesis or trophoblast cells obtained from the chorion we are able to define baby's sex perfectly. However, this method is invasive and is used only to confirm or to exclude suspected fetal abnormalities as the estimated risk of defects outruns the risk of possible complications [6,7]. We attain nearly $100 \%$ certainty by evaluating the cell-free fetal DNA taken from maternal circulation with the use of genome sequencing technique [8]. It is more and more widely used, especially in the case of suspected genetic disorders correlated with sex [9]. For example, it concerns male fetuses with Duchenne muscular dystrophy and congenital adrenal hypertrophy which can lead to intrauterine virilization of female fetuses and developing external hermaphrodite features [9]. Currently, this method is used to a limited extent only. When it comes to the domestic costs, these are comparable to invasive methods. At the moment, the ultrasound is the most common method of determining fetal sex. [6,10-12]. The USG can be used for determining the sex even through the screening examination recommended by PGA (Polskie Towarzystwo Ginekologiczne Polish Gynecological Association) between the $11^{\text {th }}$ and 13.6 week of pregnancy [12]. According to Hsiano et al., in the 11 week of pregnancy the prediction of sex determination is $71.9 \%$, in the 12 month of pregnancy $92 \%$ and in the $13^{\text {th }}$ it increases to $98.3 \%$ [13]. On average, in our own studies the surveyed mothers determined the sex of their unborn babies in the $22^{\text {nd }}$ week of pregnancy (from 19 to 36 week of pregnancy) thus we can talk about determination of fetal sex in the analyzed examinations with almost $100 \%$ certainty. In the investigated group of pregnant women vast majority declared the desire to know their baby's sex (91.5\%). This percentage is comparable with the number of women declaring the desire to know the sex $(91 \%)$ in the study published in Birth in 2004 in the group of multiparas who guessed their babies' sex in previous pregnancies (13). In our own studies pregnancy parity had no influence on the way of making contact with the unborn child. In the work cited above, more than one fourth of its participants wanted to have subsequent USG examination without any medical indications in order to confirm fetal sex [13]. Our own study results also stated considerable percentage of women $(39 \%)$ declaring desire to have subsequent examination confirming identified sex.

The introduction of ultrasound into everyday obstetric practice considerably modified the scope of prenatal diagnostics [11]. It had noticeable impact on prenatal attachment of parents to their unborn children $[14,15]$. According to the published reports fetal visualization during ultrasound increases the bond between the mother and her future child [16]. According to our own studies, the majority of the subjects admitted that knowing the fetal sex facilitates building a relationship with the unborn child and allows its personification. These types of feelings were not affected by pregnancy parity, its planning or the respondents' education. Likewise, the increase of emotional bond was affected neither by education nor pregnancy parity. About $2 / 3$ of women stated that knowing the fetal sex resulted in considerable increase of their emotional bond with the unborn child. Emotional bond increases most among the surveyed with unplanned pregnancies - it concerned $79.63 \%$ of the surveyed, with $58.22 \%$ women having previously planned their pregnancies. This goes against some literature suggesting that there are no differences between planned and unplanned preg- 
nancies in terms of creating emotional bonds between the mother and the child (1). Our own results may point at the significance of USG examination on creating a bond with the unborn child. It is consistent with the papers cited above $[5,15,16]$.

\section{CONCLUSIONS}

Determination of fetal sex during ultrasonography examination facilitates making contact with the unborn child and enables the mother to prepare for childbirth considering its sex by the purchase of clothes, pram and preparing the layette or baby room. Well-planned, randomized studies are needed in order to confirm observations made in our own studies.

\section{REFERENCES}

1. Popławska E. Więź emocjonalna $\mathrm{z}$ dzieckiem $\mathrm{w}$ okresie prenatalnym. Kwartalnik Naukowy Fides et Ratio. 2011;2(6):28-39.

2. Ammanti M. Maternal representations during pregnancy and early mother-infant interaction. Inf Ment Healt J. 1991;12:246-55.

3. Benoit D, Parker KC, Zeanah CH. Mothers' representations of their infants assessed prenatally: stability and association with infants' attachment classifications. J Child Psychol Psychiatry. 1997;38(3):307-13.

4. Siddiqui A, Hagglof B, Eisemann M. An exploration of prenatal attachment in Swedish expectant womem. J Reprod Infant Psychol.1999;17(4):369-80.

5. Shettles L, Rorvik DM. Zaplanuj płeć swojego dziecka. Warszawa: Wyd. Filar; 2001.
6. Kooper AJ, Pieters JJ, Eggink AJ, et al. Why do parents prefer to know the fetal sex as part of invasive prenatal testing? ISRN Obstet Gynecol. 2012;2012:524-37.

7. Chen LC, Chen CY, Horng HC, et al. Sex ratio at a tertiary medical center in northern Taiwan--an analysis of amniocentesis; Taiwan $\mathrm{J}$ Obstet Gynecol. 2014;53(1):118-9.

8. Lau TK, Chan MK, Salome Lo PS, et al. Non-invasive prenatal screening of fetal sex chromosomal abnormalities: perspective of pregnant women. J Matern Fetal Neonatal Med. 2012;25(12):2616-9.

9. Hill M1, Taffinder S, Chitty LS, Morris S. Incremental cost of noninvasive prenatal diagnosis versus invasive prenatal diagnosis of fetal sex in England. Prenat Diagn. 2011;31(3):267-73.

10. Hickey J, Goldberg F. Diagnostyka USG w położnictwie i ginekologii. Gdańsk: Wyd. Med. Makmed;1997.p.9-23.

11. Reddy UM, Abuhamad AZ, Levine D, Saade GR. Fetal imaging: Executive summary of a Joint Eunice Kennedy Shriver National Institute of Child Health and Human Development, Society for MaternalFetal Medicine, American Institute of Ultrasound in Medicine, American College of Obstetricians and Gynecologists, American College of Radiology, Society for Pediatric Radiology, and Society of Radiologists in Ultrasound Fetal Imaging Workshop. Am J Obstet Gynecol. 2014;210(5):387-97.

12. Shipp TD, Shipp DZ, Bromley B, et al. What factors are associated with parents' desire to know the sex of their unborn child? Birth. 2004;31(4):272-9.

13. Sioda T. Psychological effects of cardiotocographic and ultrasonographic examinations in pregnancy and labour on the mother. Part I. The significance of cardiotocographic and ultrasonographic examinations for the development of maternal bonding. Ginekol Pol. 1984;55(9):653-60.

14. Fletcher JC, Evans MI. Maternal bonding in early fetal ultrasound examinations. N Engl J Med. 1983;308(7):392-3.

15. Zlotogorski Z, Tadmor O, Rabinovitz R, Diamant Y. Parental attitudes toward obstetric ultrasound examination; J Obstet Gynaecol Res. 1997;23(1):25-8.

\section{Corresponding author}

Gustaw Chołubek

tel: 502-581-676

E-mail: g.cholubek@gmail.com 